\title{
International Discourse on Child Participation in Family Justice
}

\author{
Asmidah Ahmad ${ }^{1,2}$, Noor Aziah Mohd Awal ${ }^{2} \&$ Mohd Al Adib Samuri ${ }^{3}$ \\ ${ }^{1}$ Faculty of Syariah and Law, Universiti Sains Islam Malaysia (USIM), Bandar Baru Nilai, Nilai, Negeri \\ Sembilan, Malaysia \\ ${ }^{2}$ Faculty of Law, Universiti Kebangsaan Malaysia (UKM), Bangi, Selangor, Malaysia \\ ${ }^{3}$ Sharia Law Department, Faculty of Islamic Studies Universiti Kebangsaan Malaysia (UKM), Bangi, Selangor, \\ Malaysia \\ Correspondence: Asmidah Ahmad, Faculty of Syariah and Law, Universiti Sains Islam Malaysia (USIM), \\ Bandar Baru Nilai, 71800 Nilai, Negeri Sembilan, Malaysia. Tel: 60-17-287-0044. E-mail: \\ asmidah@usim.edu.my
}

Received: September 9, $2015 \quad$ Accepted: November 25, $2015 \quad$ Online Published: December 21, 2015
$\begin{aligned} & \text { doi:10.5539/ass.v12n1p96 } \\ & \text { URL: http://dx.doi.org/10.5539/ass.v12n1p96 }\end{aligned}$

\begin{abstract}
Family justice has undoubtedly molded in an interesting shape throughout the century. Recent development upholds the sovereignty of children's right over the traditional paternalistic and maternal preference in deciding matrimonial disputes. Affording right to children to participate in matrimonial proceeding will surely be debatable and bring about further complex issues to the proceeding since children are viewed as vulnerable group who must be protected from any harm. Hence, this article intends to review the international discourse ranging from the children's right and family justice as undertaken internationally and provides commentary on Malaysian current practice. Results indicated that statutory provisions in Malaysian laws value the wishes of a child only in custody cases but the practice is slightly erratic as distinctive judges have different practices. It is submitted that a comprehensive guideline on judicial procedure are then required to be developed in ensuring that Justice must not only be done; but must be seen to be done to all parties including the children.
\end{abstract}

Keywords: children's rights, right to be heard, participation, family justice, custody dispute

\section{Introduction}

History portrayed the remarkable changes of direction prior to $20^{\text {th }}$ century when children were considered as the wealth of fathers. It continued developing to indicate mothers as the appropriate guardian of the children due to tender years' doctrine. The law progressed further by advancing joint custody that mirrors the perfect custom that both parents are inherently imperative towards child development. More recently, the proclamation of the United Nations Convention on the Rights of the Child (the Convention) offers an astounding development in extending children as right-holders with a fitting direction given by their guardians.

The essential principle that highlights the rights of children can be seen in Article 12 of the Convention that fundamentally gives them a privilege to be heard in any matters that influence their lives. Their views should be given serious consideration in deciding any dispute in the event their parents get a divorce. The article reads as follow:

Art.12.1: State parties shall assure the child, who is capable of forming his or her own views, the right to express those views freely in all matters affecting the child, the views of the child being given due weight in accordance with his or her age and maturity.

Art. 12.2: For this purpose, the child shall in particular be provided the opportunity to be heard in any judicial and administrative proceedings affecting the child, either directly or through a representative or an appropriate body, in a manner consistent with the procedural rules of national law.

This article is regarded as the most remarkable development brought by the Convention in acknowledging them as a full person with integrity, personality, and capacity to completely participate in any judicial and administrative proceedings.

In any case, it has been challenging to make this practice meaningful, justifiable and successful notwithstanding the expanding expectation of children's participation in policy-making and decisions affecting them (Singer, 
2014). It truly depends on the culture, religion and legislative framework of countries in guaranteeing the relevancy of the Convention provisions in their respective settings. It is worth to embrace the theoretical structure for research in child advocacy as it engages inter-disciplinary undertakings in ensuring the children's empowerment as personhood (Cascardi et al., 2015). Such an activism refers to any action intended to empower or elevate the status of children by promoting their self-expression and participation, while recognizing that the improved status of children depends on the welfare of the families and communities in which they belong to.

\section{International Discourse on Providing Rights to Children}

The development of the Convention offers impeccable and reparable point and option towards equity in family law. It appears as a fundamental indication of international human rights law; hence, it has impelling and progressing implications in research, law and policy on children's right (Mitchell, 2005). In effecting such, the state parties are entrusted to make the Convention's provisions "generally known, by appropriate and active means, to adults and children alike" as provided in Article 42 of the Convention. This leads to an enormous volume of international academic discourse on the impact of the Convention to current domestic legislative settings (Fenton-Glynn, 204; Woodhouse, 2014).

The sharing of information and experiences by other state parties might be the preliminary stage of leading unthinkable solutions to address current predicaments in cases of family justice. There is a fundamental body of research currently supporting the privileges of children's participation (Cashmore \& Parkinson, 2009; Halpenny et al., 2008; Sutherland, 2014). The most influential advantages of listening to children are summarized as the following attributes, including but not limited to child's social-emotional development and judicial virtues. Children also experience a range of magnitudes from increased self-esteem and strengthened accountability to positive children's socialization and consistent family relations. In addition, listening to children in some avenue leads the court to better decision-making and prepares the children to participate in civil society.

Moreover, the literature predominantly pays attention to several dimensions on children's participation, namely benefits and risks, models (Taylor et al., 2012), forms which connote direct or indirect involvement of children in any legal proceeding, methods of hearing children's voices and opinions (Fernando, 2014; Parkes, 2013) as well as rights to participation, but still lacking on the 'best practice' in children's participation in family law decision-making universally, including what mechanisms, procedures and practices are in place to support family courts, professionals, parents, policy makers and, of course, children themselves in local settings (Taylor et al., 2012).

\subsection{Defining Children's Participation}

Children's participation in the course of matrimonial proceedings remains a controversial argument. It is a perfect combination of laws reflecting the beliefs and cultures of a specific nation. The way childhood is experienced in one community or one family vary accordingly since there is no universal model of child-raising and childcare (Lambert, 2012). Special characteristics of people in various geographical areas prove the presence of different legal systems underlining the shapes of child and family law. This event subsequently leads to pivotal debate among scholars on the issue of children's right in relation to private family settings.

Participation is something that excites interest, but proven to be difficult to define. A significant body of literature has been created to clarify participation, and these works offer explanations on the concept of participation ranging from universal to focused and project-specific perspectives (Charles \& Haines, 2014). It depends truly on the nature of event it is attached to. In practice, the term participation is often used simply to mean being 'listened to' or 'consulted'. In this sense, the term connotes an extremely inactive undertone (Lansdown et al., 2014). This is in contrast to active participation, which could imply on the presumption that the children, in one way or another, have the power to make a difference with their involvements. Participation in this context is undertaken with the very specific purpose of enabling children to influence decision-making and bring about change, whether this is in respect to decisions about individuals, wealth management services, decision-making structures, adult-child relationships or organizational cultures.

\subsection{The Prevailing Interest}

Apart from that, debates on the responsibility of parents against rights of children should not be disregarded in measuring the circumstances in divorce cases. The way in which the best interests test interacts with the concept of children's rights remains an obvious truth that is unfortunately being ignored and not being properly addressed (Fortin, 2009). The child's best interest belief, which is provided in Article 3 of the Convention, must be compatible with a commitment to hear a child as envisaged in Article 12 of the Convention (Dale, 2014). Dale further suggests the child's preferences and voice should be included in best interest's determinations in 
determining cases of parental conflict. The child must be treated as a human being who possesses the right as a person in accordance with scientific findings that prove children develop their sense of preference before they can walk and talk. Findings on children's cognitive, adaptation and communication skills have shown that children, from a very young age, are already able to interact actively with the surrounding world thus contributing to how they are capable of building their relationship with adults (Bosisio, 2012).

These commitments show the balance relevancy between the importance of Article 3 and Article 12 of the Convention which ought to be thought of as having equality in force and standing, not least since the Convention views all of its Articles as having the same binding power upon States (Archard \& Sivenes, 2009). These observations show that the Convention aimed at empowering children with the right to decide in their best interests. Despite the fact that children are incapable of decision-making, this right should neither be suppressed by the court nor ignored by the parents. Such right must be preserved as children are also considered as having the right to remedy through an appeal or complaints procedure in any event such right is neglected. Noteworthy in December 2011, the UN General Assembly adopted the Third Optional Protocol to the UN Convention that introduces a new complaint procedure. This is designed to allow individuals or groups or their representatives to claim that a state party who has ratified the treaty has infringed their rights. Arguably, the Optional Protocol will invigorate the Convention, but it will be useless to children unless Malaysia signs and ratifies it.

To ensure the pursuit of justice, which employs an adversarial mode of trial in family battle, is attainable, numerous countries are undergoing significant changes in introducing children's participation in family law decision-making process. It is therefore aimed at giving a considerable proportion of opportunity to adult and children to be heard fairly in court. Undeniably, children are treated equal of having procedural rights to justice (Landsdown, 2005) but the protection of parents' well-being must not be overlooked (Eekelaar, 2002). Landsdown contended that the entire document of the Convention acknowledged the children's right to participation as he held the view that participation is seen as both substantive and procedural rights that respectively entitles children to be heard to and to act further in promoting other rights. It is often an issue of how judges might balance the principle of fairness to parents as well as the welfare of a child in judging family disputes. Decisions that maintain some stability within the power imbalances inside families may also influence on how the relationships between generations are developed and exercised (Eekelaar \& Maclean, 2013).

\subsection{Scope of Reference and Methods}

Participation involves several dimensions and aspects (Sinclair, 2004). It is clear that enormous facets are now associated with children's participation, such as in family legal proceedings involving custody (Fernando, 2014; Yusoff, 2014; Sutherland, 2014) and adoption (Fenton-Glynn, 2014; Sloan, 2013), in criminal proceedings involving juvenile justice (Henning, 2010), in health decision-making (Coyne, 2008; Donnelly \& Kilkelly, 2011) and within the educational sphere (Lundy, 2007). The protection of children's rights in relation to public law can be seen in so many domestic legal settings as opposed to private law despite the development of literature discussing the effect of Article 12 of the Convention. If children's voices were heard less in the private sphere of the family than when they were in public sphere, then it would be ironic.

The practice of children's participation in matrimonial disputes can be done through various means which includes a representation of a child by a lawyer (Bala, 2013), a meeting between a judge and a child (Erikson \& Nasman, 2008; Fernando, 2013; Hendrick, 2011) or even through a report provided by an expert (Fernando, 2014; Taylor et al., 2012). Despite various possible methods of hearing children's view, many believe that meeting with children is more effective to yield useful evidence of children's views and give judges greater understanding of the needs and best interests of each child. Bear in mind that children's participation has to be voluntary and by their own choice, based on informed consent and respecting their right not to participate (Sinclair, 2004).

Participation can also be sought by informing children about what is happening in the divorce rather than leaving them to imagine what it means (Cashmore \& Parkinson, 2009). The children's inclination to participate does not necessarily mean they want to be a decision maker, but they think such practice is one of the main determinants of the perception that the decision-making process is reasonable, even though the result is not what the particular case needs (Parkinson \& Cashmore, 2008). To deliver the task of taking children seriously, an adult needs to develop a mind-set and skills to translate the principle into practice (Cashmore, 2011). It is obvious that the primary task of an adult is not just lending an ear to whatever they wish or need, but it requires taking into account the children's views in the process of decision-making.

\section{Position in Malaysia}

The debate on children's rights in cases relating to parental privileges (Griffiths et al., 2013), especially in 
matters concerning custody of children after divorce, always welcomes criticism. The issues range extensively from the very definition (Malek, 2001) to the inconsistency of enforcement (Siraj, 2012). Siraj once criticized the decision ruled in Amarapathi a/p Periasamy v Muniandy a/l Periasamy [2005] 3 MLJ 49 stating that the Guardianship of Infants Act 1961 (Revised 1988) cannot be relied by a foster parent to maintain her claim for custody of a girl against the natural father. She respectfully argued that if the Federal Court is correct in its interpretation, then this reveals the inadequacy of Malaysian's family laws relating to custody of children.

Another clear illustration can be seen in a problem of defining the term of welfare or 'best interest' principle. It leads to judges' discretionary power to interpret the connotation according to the fact of cases that they preside over. Vernon Ong JC in Tay Chuen Siang v Wang, Chiao-Wen [2009] 9 CLJ 84 said:

"The court, however, is not precluded from considering any other factors which may be relevant or have an effect on the children's welfare. It is trite that the welfare of the children is paramount. What do we mean by the term 'welfare of the child'? The word 'welfare' is defined by the Cambridge Advanced Learner's Dictionary, $2^{\text {nd }}$ edn., as 'physical and mental health and happiness, especially of a person'. Clearly then, the court must have the physical and mental health and happiness of the children as its overriding consideration."

It is an established fact that different religious personal laws which operate in a country simultaneously will undoubtedly bring its own challenges (Sutherland, 2012). This is evidenced with the advent of recent edict issued by Perlis Fatwa Committee whom boldly opined the same footing as in the above case for promoting the child's right to choose between parents with whom they prefer to reside in custody battles involving Muslim convert and non-Muslim parents provided the child is competent enough to decide so. The effort is plausible even though it brought varies perspectives from fellow legal practitioners and NGOs since the child welfare is put on priority over Islamic religion. The provocative reaction does not help soothing the battle (Samuri \& Quraishi, 2014) unless and until the supporters of human right and Islamic scholars could sit together rationalizing the issue at hand and developing a harmonious solution which could perfectly work for both sides. It is nevertheless a critical sign that social awareness on child right in Malaysia is still low. Another possible option as suggested by Awal is by extending the jurisdiction of the High Court in appointing a special referee as provided in the Court of Judicature Act 1964 in matters involving family issues of different races and religions in safeguarding the racial relation and children's welfare in Malaysia (Awal, 2012).

Besides, it is interesting to note that the enforcement of the Convention is monitored through a softer method of self-reporting by state parties as provided in Article 44(1) of the Convention whereby the submission of a progress report is required two years after ratification of the Convention and every five years thereafter. Malaysia has for the first time experienced the self-reporting cycle whereby the Committee of the Convention observed Malaysia's initial report in 2007 by providing their concluding observations and recommendations, especially on the issue of insufficient attention being given to child's rights under Article 12 to express his or her opinion. Among the crucial recommendations made by the committee was that children's views should be systematically heard and taken into consideration in all judicial, administrative and other decisions affecting them, depending on the children's age and maturity. This was made in response to our admission to the fact that "in legal and administrative proceeding, it is in practice left to the discretion of the judge to decide whether the child is heard". The Committee further expressed their regret that the Child Act 2001 (Act 611) does not contain a specific provision on children's participation.

Remarkably, apart from all polemics discussed above, Malaysian courts value the wishes of a child as embedded in its legislation as revealed in section 88 of the Law Reform (Marriage and Divorce) Act 1976 and section 86 of the Islamic Family Law (Federal Territory) Act 1984. It is also evidenced through judicial practices, which favour the direct approach of children's participation as ruled in M Saraswathi Devi a/p K Govind v Keith Ian Monteiro [2006] 1 CLJ 303 where the court varied the previous judgment and granted custody order to the father after interviewing a 14 year old son personally in his learned's chamber despite engaging expert opinions in deciding custody disputes. Hence, quarters of family law practitioners believe that this can have harmful and detrimental effects to the children as judges are not experts in child psychology and counselling (Azizan, 2011). The claim remarks that conscience as practiced is slightly varying since different judges tend to have diverse practices. There is no consensus on basic practice procedures in dealing with family law cases.

While unanimity has developed around the significance of considering children's wishes and emotions, there is still contradiction about how this ought to be accomplished (Caffrey, 2013). The uncertainty of procedures in judging family disputes lead to the use of wide discretionary power by judges in determining the best approach in upholding the children's wishes in presiding cases before them. Thus, the way that judges exercise discretion 
in family justice proceedings profoundly defines to what extent such children's voices can be heard in those proceedings (Raitt, 2004) and at the same notion, might risk the rights of the children to be heard fairly.

\section{Islamic Perspective on the Right of Child Participation}

The Quran prescribes the limitation of child and parents' relation whereby it is a very serious sin to disobey one's parents. The Quran says:

And do well unto [thy] parents. Should one of them or both, attain too old age in thy care, never say 'Ugh' to them or scold them, but always speak unto them with reverent speech and spread over them humbly the wings of thy tenderness and say: 'O my sustainers! Bestow Thy grace upon them, as they cherished and reared me when I was a child.

(Al-Quran Surah Al-Isra': 23-24)

These verses impliedly stress the importance of reciprocal relationship between child and parents. The child owes a duty to pay their parents respect as the parents owe parenthood responsibility towards children. The same principle should be preserved if a divorce occurs. Based on the same notion, mutual love and respect should be maintained amongst them in ensuring the preservation of family relations even after a marriage discord.

Justice is absolutely intended to be spread equally to all parties at stake. The judge must be able to value the views' given by the disputing parties as well as the children in deciding custody matters. Justice is indeed a Quranic commitment which is why the Prophet saw was told:

We have revealed to you the Book with the truth that you may judge between people by what God has taught you.

(Al-Quran Surah Al-Nisa': 105)

Sayyid Qutb drew a conclusion after studying the Quran that justice is an inherent right of all human beings under the Shariah (Kamali, 2002). The child is hence included within perspective. It is undoubtedly sufficed to put the task on determining child's best interest upon divorce on the judge's shoulder since parents are presumably incapable to reach a common decision. He must be then someone who is impartial and knowledgeable in ascertaining the best solution for the sake of child's welfare. It is therefore submitted that all reforms given to current family law framework nowadays, especially the notion of child's best interest principle and child's right to be heard, are within the ambit of Quranic teaching.

\section{Conclusion}

The endeavour shown by developed countries in portraying their serious commitment in the current debate on children's right to be heard significantly advances clear indication that, apart from the existing legislation, additional legal mechanism is also necessary to implement family justice. It is undeniably necessary to develop and establish universally acceptable guideline to act as reliable indicators in order to compare outcomes associated with various initiatives of children's participation adopted by state parties. Irrefutably, child interviewing in family disputes as practiced currently in Malaysia should be maintained as the best approach, but such practice must be done in delicate manners considering the subject matter is a child at tender age. It is a considerable advantage for having judges with interdisciplinary knowledge in dealing with complicated cases involving children. This is crucial to achieve the objective in providing a better tomorrow for children in ensuring their voices are reasonably heard, especially in matters concerning marital separation of their parents.

\section{Acknowledgments}

The research is funded by Fundamental Research Grant Scheme (FRGS/1/2014/SSI10/USIM/03/1) to obtain insight on children's right and family justice in order to develop a module of matrimonial proceeding judicial procedure in ensuring the protection of children's rights to be heard in Malaysia. Special thanks are due to Islamic Finance and Wealth Management Institute (IFWMI) of USIM for organizing special workshop on journal publication dated May 2015.

\section{References}

Al-Quran.

Archard, D., \& Skivenes, M. (2009). Balancing a Child's Best Interests and a Child's Views. International Journal of Children's Rights, 17(1), 1-21. http://dx.doi.org/10.1163/157181808X358276.

Awal, N. A. M. (2012). Malaysia: What lies ahead? In E. E. Sutherland (Ed.), The Future of Child and Family Law: International Predictions (pp. 205-234). Cambridge: Cambridge University Press. 
Azizan, H. (2011). Suffer the Children. The Star.

Bala, N., Birnbaum, R., \& Bertrand, L. (2013). Controversy about the Role of Chilren's Lawyers: Advocate or Best Interests Guardian? Comparing Practices in Two Canadian Jurisdictions with Different Policies for Lawyers. Family Court Review, 51(4), 681-697.

Bosisio, R. (2012). Children's Right to Be Heard: What Children Think. The International Journal of Children's Rights, 20(1), 141-154. http://dx.doi.org/10.1163/157181811x573462

Caffrey, L. (2013). Hearing the 'voice of the child'? The Role of Child Contact Centres in the Family Justice System. Child and Family Law Quarterly, 25(4), 357-379.

Cascardi, M., Brown, C., Shpiegel, S., \& Alvarez, A. (2015). Where Have We Been and Where Are We Going? A Conceptual Framework for Child Advocacy. SAGE Open, 5(1). http://dx.doi.org/10.1177/21582440 15576763

Cashmore, J. (2011). Children's participation in family law decision-making: Theoretical approaches to understanding children's views. Children and Youth Services Review, 33(4), 515-520. http://dx.doi.org/10.1016/j.childyouth.2010.05.008

Cashmore, J., \& Parkinson, P. (2009). Children's Prticipation in Family Law Disputes. Family Matters, (82), 15-21.

Charles, A., \& Haines, K. (2014). Measuring Young People's Participation in Decision-Making. International Journal of Children's Rights, 22(3), 641-659. http://dx.doi.org/10.1163/15718182-55680022

Coyne, I. (2008). Children's Participation in Consultations and Decision-Making at Health Service Level: A Review of Literature. International Journal of Nursing Studies, 45(11), 1682-1689.

Dale, M. D. (2014). Don't Forget The Children: Court Protection from Parental Conflict is in the Best Interests of Children. Family Court Review, 52(4), 648-654. http://dx.doi.org/10.1111/fcre.12116

Donnelly, M., \& Kilkelly, U. (2011). Child-friendly healthcare: delivering on the right to be heard. Med Law Rev, 19(1), 27-54. http://dx.doi.org/10.1093/medlaw/fwq034

Eekelaar, J. (2002). Beyond the Welfare Principle. Child and Family Law Quarterly, 14(3).

Eekelaar, J., \& Maclean, M. (2013). Family Justice: The Work of Family Judges in Uncertain Times (1st ed.). United Kingdom: Hart Publishing Ltd.

Eriksson, M., \& Näsman, E. (2008). Participation in Family Law Proceedings for Children Whose Father is Violent to Their Mother. Childhood, 15(2), 259-275. http://dx.doi.org/10.1177/0907568207088426

Fenton-Glynn, C. (2014). The Child's Voice in Adoption Proceedings. The International Journal of Children's Rights, 22(1), 135-163. http://dx.doi.org/10.1163/15718182-55680018b

Fernando, M. (2013). Children's Direct Participation and the Views of Australian Judges. Australian Institute of Family Studies, (92), 40-47.

Fernando, M. (2014). Family Law Proceedings and the Child's Right to be Heard in Australia, the United Kingdom, New Zealand and Canada. Family Court Review, 52(1), 46-59.

Fortin, J. (2009). Children's rights and the developing law (3rd ed.). Cambridge University Press.

Griffiths, A., Fotheringham, J., \& McCarthy, F. (2013). Family Law (3rd ed.). Edinburgh: W. Green \& Son Limited.

Halpenny, A. M., Greene, S., \& Hogan, D. (2008). Children's Perspectives on Coping and Support following Parental Separation. Child Care in Practice, 14(3), 311-325. http://dx.doi.org/10.1080/13575270802041720

Hendrick, J. (2011). When Should the Judge and the Child Meet? Family Law, 41, 1148-1151.

Henning, K. (2010). Denial of the Child's Right to Counsel, Voice, and Paticipation in Juvenile Delinquency Proceedings. Child Welfare, 89(5), 121-136.

Kamali, M. H. (2002). Freedom, Equalityand Justice in Islam. Malaysia: Ilmiah Publishers Sdn Bhd.

Lambert, B. A. (2012). The Challenge of Hearing the Voice of the Child: No Matter How Hard One Listens.

Landsdown, G. (2005). The Evolving Capacities of the Child. Italy: UNICEF Innocenti Research Centre.

Lansdown, G., Jimerson, S. R., \& Shahroozi, R. (2014). Children's rights and school psychology: children's right to participation. $J$ Sch Psychol, 52(1), 3-12. http://dx.doi.org/10.1016/j.jsp.2013.12.006 
Lundy, L. (2007). 'Voice' is not enough: conceptualising Article 12 of the United Nations Convention on the Rights of the Child. British Educational Research Journal, 33(6), 927-942. http://dx.doi.org/10.1080/ 01411920701657033

Malek, N. A. (2001). Factors Determining Welfare of the Child in Malaysian Civil Law of Custody: An Analysis of Decided Cases. Jurnal Undang-undang \& Masyarakat, 15, 169-178.

Mitchell, R. C. (2005). Postmodern Reflections on the UNCRC: Towards Utilising Article 42 as an International Compliance Indicator. The International Journal of Children's Rights, 13, 315-331.

Parkes, A. (2013). Children and International Human Rights Law (1st ed.). London: Routledge.

Parkinson, P., \& Cashmore, J. (2008). The Voice of a Child in Family Law Disputes: Oxford: Oxford Universiy Press.

Raitt, F. E. (2004). Judicial Discretion and Methods of Ascertaining the Views of a Child. Child and Family Law Quarterly, 16(2), 1-15.

Samuri, M. A. A., \& Quraishi, M. (2014). Negotiating Apostasy: Applying to "Leave Islam" in Malaysia. Islam and Christian-Muslim Relations, 25(4), 507-523. http://dx.doi.org/10.1080/09596410.2014.907054

Sinclair, R. (2004). Participation in practice: making it meaningful, effective and sustainable. Children \& Society, 18(2), 106-118. http://dx.doi.org/10.1002/chi.817

Singer, A. (2014). Voices heard and unheard - A Scandinavian perspective. Journal of Social Welfare and Family Law, 36(4), 381-391. http://dx.doi.org/10.1080/09649069.2014.967986

Siraj, M. (2012). Resolving Child Custody Disputes: The Law and Practice in Malaysia (1st ed.). Malaysia: LexisNexis.

Sloan, B. (2013). Conflicting Rights: English Adoption Law and the Implementation of the UN Convention on the Rights of the Child. Child and Family Law Quarterly, 25(1).

Sutherland, E. E. (2012). Imperatives and challenges in child and family law. In E. E. Sutherland (Ed.) The Future of Child and Family Law: International Predictions (pp. 1-46). [Online]. Cambridge: Cambridge University Press. http://dx.doi.org/10.1017/CBO9781139035194.002

Sutherland, E. E. (2014). Listening to the Child's Voice in the Family Setting: from Aspiration to Reality. Child and Family Law Quarterly, 26(2), 152-172.

Taylor, N., Fitzgerald, R., Morag, T., Graham, A., \& Bajpai, A. (2012). International Models of Child Participation in Family Law Proceedings following Parental Separation / Divorce. The International Journal of Children's Rights, 20(4), 645-673. http://dx.doi.org/10.1163/15718182-55680006

Woodhouse, B. B. (2014). Listening to children: Participation rights of minors in Italy and the United States. Journal of Social Welfare and Family Law, 36(4), 358-369. http://dx.doi.org/10.1080/09649069.2014. 967983

Yusoff, R. C. S. (2014). Children's Participation in Custody and Access Proceedings. IIUM Law Journal, 22(1), 53-73.

\section{Copyrights}

Copyright for this article is retained by the author(s), with first publication rights granted to the journal.

This is an open-access article distributed under the terms and conditions of the Creative Commons Attribution license (http://creativecommons.org/licenses/by/3.0/). 